\title{
ANALISIS HUMAN RESOURCE DEVELOPMENT, COMMUNITY DEVELOPMENT, DAN NETWORKING, DALAM MEMPENGARUHI COMPETITIVE ADVANTIGE PERGURUAN TINGGI KEAGAMAAN ISLAM DI INDONESIA
}

\author{
Sutiah $^{1}$ \\ ${ }^{1}$ Jurusan Pendidikan Agama Islam, UIN Maulana Malik Ibrahim Malang \\ bu_sutiah@yahoo.com
}

\section{Info Artikel \\ Riwayat Artikel: \\ Diterima: November 2019 \\ Direvisi: Agustus 2019 \\ Diterbitkan: September 2019}

\section{Keywords:}

Human Resources

Development (HRD)

Community Development

Analysis (CDA)

Networking

Commpetitive Advantage

Islamic Religious College

\begin{abstract}
Today every university including PTKIN cannot avoid continually being prepared and competing with various other universities both at national and international levels. In winning the competition and replying to higher education the competitive advantage factor is taken into account. High performance of university which is based on three aspects, namely cost-based, product-based, and service-based. PTKIN must have quality and service excellence, as well as the ability to compete in the costs and excellence of majors / study programs offered. There are many factors that influence highly competitive universities, including the factors of human resource development, community development (analysis of community development) and the ability to build networks and cooperation. This study tries to annul the most dominant factors towards competitive advantage . The study took samples of Lecturers and Education Personnel at PTKIN UIN Malang, UIN Surabaya, UIN Jogjakarta, and UIN Bandung using simple random techniques. The sample of respondents is 200 people and check. Statistical analysis used multiple regression components of the Multivariate Principle. Research (1) The results showed (1) All the variables of Human Resource Development (HRD), Community Development Analysis (CDA), and Network \& Cooperation (NP) related to Competitive Advantage (CA) or PTKIN competitiveness (production quality), quality of service (quality of service), also competitive advantage in financing and quality of safety management (price) unless the CDA converter variable is smaller than the others. (2) HRD variable regression coefficient value of 0.714 . Increasing $\mathrm{HRD}$, CA will also increase by 0.714 or $71.4 \%$ of the CDA variable value of -0.168 . This means, if other factors are considered constant, there is no direct effect of CDA on CA or smaller than HRD and NP because the results are -0.168 . While the NP variable value is 0.409 . This means, for each increase in NP, CA will also increase by 0.409 or $40.9 \%$. (3) The results of simultaneous testing show differences in variation together between HRD, CDA, NP against CA is $75.8 \%$ or accepted $24.2 \%$ is used by other factors that are not rejected. From the results of this study, PTKIN is important for developing HR (HRD) and increasing network and quality cooperation (NP) as well as developing CDA to increase PTKIN's competitiveness towards international class or WCU (Word Class University).
\end{abstract}

Copyright $@ 2019$ JRCE. 


\section{Korespondensi:}

Sutiah,

UIN Maulana Malik Ibrahim Malang,

J1. Gajayana No. 50 Malang, Jawa Timur, Indonesia 65144

bu_sutiah@yahoo.com

\section{PENDAHULUAN}

Pengembangan sumber daya manusia (human resources development) di perguruan tinggi keagmaan Islam menjadi salah satu key point dalam membangun keunggulan kometitif menuju Word Class University (WCU). Kemajuan dan kemunduran suatu lembaga pendidikan tinggi ditentukan oleh kualitas SDM. Pemerintah melalui kementrian agama secara terus menerus mendorong Perguruan Tinggi Keagamaan Islam Negeri (PTKIN) di seluruh Indonesia untuk mengembangkan kualitas`SDM dan meningkatkan mutu institusinya. Dalam mencapai keunggulan kompetitif dan mampu bersaiang di pasar global, faktor lain yang harus dikembagkan PTKIN adalah melakukan pemberdayaan masyarakat (Community development) dan membangun hubungan kemitraan (networking). Faktor community development merupakan strategi membagi tanggung jawab (responsibility), dari dalam perguruan tinggi sebagai organisasi sampai ke luar perguruan tinggi pada aktivitas-aktivitas lokal yang relevan untuk memahami perilaku sosial dan lingkungan. Sedangkan Hubungan kemitraan (networking) dibangun untuk memperkuat eksistensi dan peningkatan pertumbuhan dan perkembangan Pendidikan Tinggi Keagamaan Islam Negeri (PTKIN) menjadi lebih baik dalam mewujudkan standar nasional Pendidikan Tinggi (SNPT)

Perguruan tinggi memiliki peran yang strategis dalam membangun sumber daya manusia Indonesia yang unggul. Dalam UU No. 12 Tahun 2012 Pasal 4 disebutkan bahwa fungsi pendidikan tinggi mengembangkan kemampuan dan membentuk watak serta peradaban bangsa yang bermartabat dalam rangka mencerdaskan kehidupan bangsa. Menurut Conny R. Semiawan (1998:33) pendidikan tinggi berfungsi mempersiapkan peserta didik menjadi manusia yang memiliki prilaku, nilai, dan norma sesuai sistem yang berlaku sehingga mewujudkan totalitas manusia yang utuh dan mandiri sesuai tata cara hidup bangsa. Perguruan tinggi keagmaan islam mempunyai peran besar dalam mengantarkan bangsa Indonesia sebagai warga dunia. Peran PTKI sebagaiman disebutkan dalam "World Declaration on Higher Education for the Twenty First Century: Vision and Action" yang dikeluarkan oleh UNESCO, menyatakan bahwa misi dan fungsi Perguruan Tinggi adalah membantu untuk memahami, menafsirkan, memelihara, memperkuat, mengembangkan, dan menyebarkan budaya-budaya historis nasional, regional dan internasional dalam pluralisme dan keragaman budaya.

Perkembangan dan kemajuan ilmu pengetahuan dan teknologi informasi yang pesat serta tantangan kompetisi dalam masyarakat gobal meniscayakan perubahan besar dalam pengelolaan perguruan tinggi islam menuju standar universitas kelas dunia (word-class university). Menurut Swasta Edy Suandi Hamid, Pembina Badan Kerjasama Perguruan Tinggi Islam mengatakan bahwa dari 400 perguruan tinggi islam di Indonesia baru tiga yang menuju sebagai universitas dunia sehingga harus ditingkatkan mengingat besarnya potensi PTI dalam berkonstribusi bagi kemajuan bangsa. Kondisi ini mendorong setiap organisasi termasuk pendidikan tinggi islam untuk mengikuti dan berkembang sejalan dengan perkembangan dan kemajuan perguran tinggi islam menjadi semakin kompleks dan memasuki persaingan yang semakin ketat. Hal ini menuntut pula terjadinya pergeseran- pergeseran paradigma dalam pengeolaan di bidang pendidikan tinggi islam. Persaingan yang bersifat global dan tajam di bidang pendidikan tinggi dapat menyebabkan terjadinya peningkatan atau penurunan jumlah mahasiswa, kepercayaan masyarakat, yang mempengaruhi pendapatan yang diperoleh lembaga-lembaga penyelenggara pendidikan tinggi islam dalam memasuki persaingan tingkat lokal sampai pada persaingan dunia. Keadaan ini membuat manajemen mencari berbagai strategi baru yang menjadikan pendidikan tinggi islam mampu bertahan dan berkembang dalam persaingan tingkat nasional bahkan tingkat dunia. Hanya lembaga pendidikan yang memiliki keunggulan pada tingkat nasional maupun internasional yang mampu bertahan dan berkembang, fleksibel memenuhi kebutuhan stakeholders, mampu menghasilkan lulusan (out put) yang bermutu, dan cost effective (Srimindarti dan Indarti, 2003).

Persaingan dapat dipandang sebagai pengelolaan sumber daya sedemikian rupa sehingga melampaui kinerja. Untuk berkompetisi secara global pendidikan tinggi islam perlu memiliki keunggulan kompetitif yang merupakan jantung kinerja lembaga pendidikan islam dalam sebuah pasar yang kompetitif. Menutut Porter (1985) menyatakan bahwa untuk mengidentifikasi sumber-sumber dan potensi keunggulan kompetitif bagi suatu perusahaan, diperlukan suatu alat analisis yang disebut konsep community development sebagai 
suatu metode memecah tanggung jawab (responsibility), dari dalam organisasi sampai ke luar organisasi pada aktivitas-aktivitas strategis yang relevan untuk memahami perilaku sosial dan lingkungan. Karena suatu aktivitas biasanya hanya merupakan bagian dari kesatuan aktivitas yang lebih besar dari suatu sistem yang menghasilkan nilai (Shank dan Govindarajan, 1997).

Competitive Advantage menurut Ismail, merupakan bagian dari tingginya kinerja (performance) sebuah organisasi, yang menurut Ismail dapat didasarkan pada tiga aspek: cost-based, product-based, dan service-based. Secara teoritis ada beberapa faktor Human Resources Development atau pengembangan SDM, yang dapat mempengaruhi keuanggulan dan daya saing Perguruan tinggi, antara lain (1) kualitas layanan SDM (dosen dan staff) atau kualitas layanan pendidikan dan pengajaran dosen, (2) Kualitas Penelitian dn Publikasi Karya Ilmiah, (3) Kualitas Pengabdian Kepada Mayarakat(PKM), dan (4) Peningkatan kualitas SDM secara berkelanjutan. Hal ini sebagaiman di ungkapkan dalam UU $14 / 2005$ dan mutu dosen PTKIN dalam melaksanakan tridarma perguruan tinggi. (Pusat Statistik Pendidikan, 2018)

Keuanggulan dan daya saing Perguruan tinggi keagamaan Tinggi Islam juga di pengaruhi seberapa peran keterlibatan perguruan tinggi dan partisipasi masyarakat. Berdasarkan analisis community development berapa faktor comdev yang dapat mempengaruhi keuanggulan dan daya saing Perguruan tinggi antara lain (1) peran atau kontrubusi perguruan tinggi dalam pengembangan kompetensi masyarakat, (2) Peran Serta atau pengikutsertaan peran masyarakat dalam comdev, (3) pengembangan program-program comdev yang sesuai dengan sectornya, dan (4) keberhasilan comdev yang relevan atau sesuai dengan karakteritik dan harapan kelompok masyarakat kepentingan (Stakeholders) Sebagaimana diungkapkan Leliugiene, I., \& Barsauskiene, V. (2003).

Faktor lain yang dapat mempengaruhi keuanggulan dan daya saing Perguruan tinggi keagamaan Tinggi Islam adalah kemampuan perguruan tinggi dalam membangun networkiing (jejaring) dan partnership (kerjasama). Kegiatan ini merupakan upaya perguruan tinggi dalam membangun jaringan sosial yang dibangun dan terdiri dari kelompok-kelompok yang saling berkomunikasi satu dengan yang lain. Menurut Lemke, J. L. (1990). Ada dua factor yang berpengaruh yaitu (1) berkelompok dan (2) berkomunikasi. Sedangkan suatu Perguruan tinggi keagamaan Tinggi Islam yang berdaya saing (competitive advantages) manakalah Perguruan tinggi tersebut memiliki keunggulan-keunggulan dalam mutu lulusan, keunggulan layanan dan mamapu bersaing dalam harga maupun program studi yang ditawarkan. Sebagaimana diungkapkan Ismail, A. I., Rose, R. C., Uli, J., \& Abdullah, H. (2012). Competitive advantages merupakan bagian dari tingginya kinerja (performance) sebuah organisasi, yang menurut Ismail dapat didasarkan pada tiga aspek: cost-based, product-based, dan service-based.

Dari masalah PTKIN UIN yang didukung oleh kajian teori dan hasil penelitian terdahulu, maka disusunlah kerangka pemikiran bahwa Competitive Advantages (CA) sebagai (Y) PTKIN UIN di Indonesia dipengaruhi oleh variabel, Human Resources Development (HRD) (X1),Community Development Analysis (CDA) (X2), dan Network \& Patnership (NP) (X3). Berangkat permasalahan diatas penelitian ini bertujuan untuk menganaisis dan mebuktikan sebagai berikut:

1. Apakah Analisis Human Resource Development memberikan pengaruh positif dan signifikan terhadap pembentukan karakter pendidikan tinggi keagaman islam negeri (PTKIN) Universitas Islam Negeri yang unggul dan kompetitif?

2. Apakah Analisis Develompment Community memberikan pengaruh positif dan signifikan terhadap pembentukan karakter pendidikan tinggi keagaman islam negeri (PTKIN) Universitas Islam Negeri yang unggul dan kompetitif?

3. Apakah networking memberikan pengaruh positif dan signifikan terhadap pembentukan karakter pendidikan tinggi keagaman islam negeri (PTKIN) Universitas Islam Negeri yang unggul dan kompetitif?

4. Bagaimana analisis Human Resource Development, Development Community dan Networking secara simultan memberikan pengaruh positif dan signifikan terhadap pembentukan karakter pendidikan tinggi keagaman islam negeri (PTKIN) Universitas Islam Negeri yang unggul dan kompetitif?

\section{METODE PENELITIAN}

Penelitian ini menggunakan pendekatan kuantitatif, jenis korelasional dengan mengkaji hubungan antara Analisis Human Resource Developmen), Community Development dan networking terhadap keunggulan kompetitif pendidikan tinggi keagamaan islam UIN di Indonesia.Dalam Penelitian ini, desain yang digunakan adalah desain deskriptif dan dilakukan pula penelaahan hubungan antara variabel (desain kausal) yang berguna untuk mengukur hubungan antara variabel riset atau untuk menganalisis bagaimana pengaruh suatu variabel terhadap variabel lainnya. Dalam penelitian ini data dihimpun secara ex post facto, 
dengan kata lain peneliti mengandalkan pada presepsi responden untuk menerangkan pengalamanpengalamannya dan selalanjutnya dianalisis menurut desaian deskriptif dan kausal.

Hubungan kausalitas ini Secara umum disajikan pada gambar 3.1 di bawah ini:

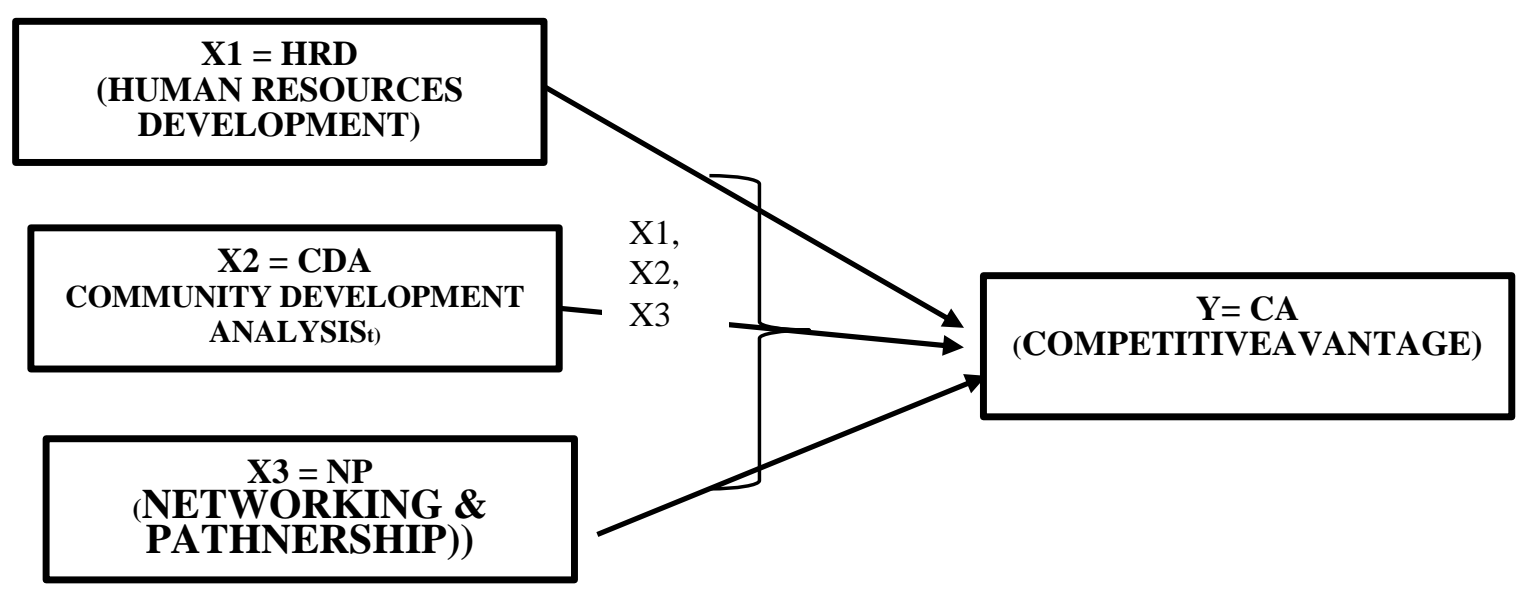

Gambar 1. Kerangka Penelitian.

\section{HASIL DAN PEMBAHASAN}

Regresi antara variable HRD, CDA, NP terhadap CA dapat digambarkan dalam pengolahan data dengan software SPSS versi 19.00 Nilai R2 (koefisien determinasi) sebesar 0,758.

Hal ini menunjukkan bahwa besarnya variasi yang memberikan pengaruh bersama-sama anatar HRD, CDA, NP terhadap CA sebesar $75,8 \%$ atau sisanya $24,2 \%$ dipengaruhi oleh faktor-faktor lain yang tidak diteliti.

Tabel. 1. hasil Estimasi Regresi Linear Berganda

\begin{tabular}{|c|c|c|c|c|c|}
\hline \multirow{2}{*}{ Model } & \multicolumn{2}{|c|}{$\begin{array}{c}\text { Unstandardized } \\
\text { Cofficients }\end{array}$} & $\begin{array}{c}\text { Standardized } \\
\text { Cofficients }\end{array}$ & & \\
\cline { 2 - 6 } & B & Std. Error & Beta & T & Sig. \\
\hline 1(Costant) & .271 & .438 & & .620 &, 537 \\
HRD & .714 & .084 & .660 & 8.493 &, 000 \\
NP & .409 & .103 & .321 & 3.987 &, 000 \\
CDA &,- 168 & .103 & -.131 & -1.628 &, 108 \\
\hline
\end{tabular}

a dependen $\mathrm{Y}$

3.1.1. Variabel HRD terhadap CA

Ho = tidak ada pengaruh HRD terhadap CA

$\mathrm{Ha}=$ ada pengaruh HRD terhadap CA

Dari perhitungan didapatkan nilai signifikansinya untuk variabel HRD adalah $0,000<0,05$ maka Ho ditolak atau Ha diterima. Dengan demikian ditarik kesimpulan variabel HRD memiliki pengaruh yang signifikan terhadap variabel CA.

3.1.2. Variabel CDA i terhadap Variabel CA

$\mathrm{Ho}=$ tidak ada pengaruh CDA terhadap CA

$\mathrm{Ha}=$ ada pengaruh CDA terhadap CA.

Dari perhitungan didapatkan nilai signifikansinya untuk variabel CDA adalah 0,000<0,05 maka Ho ditolak atau Ha diterima. Dengan demikian ditarik kesimpulan variabel CDA memiliki pengaruh yang signifikan terhadap variabel CA.

3.1.3. Variabel NP terhadap Variabel CA

$\mathrm{Ho}=$ tidak ada pengaruh NP terhadap CA

$\mathrm{Ha}=$ ada pengaruh NP terhadap CA.

Dari perhitungan didapatkan nilai signifikansinya untuk variabel NP adalah 0,108<0,05 maka Ho diterima atau Ha ditolak. Dengan demikian ditarik kesimpulan variabel NP tidak memiliki pengaruh yang signifikan terhadap variabel CA 
Diperoleh nilai koefisien regresi pada variabel HRD adalah sebesar 0,714. Ini berarti bahwa dengan faktor lain dianggap konstan, maka setiap peningkatan HRD maka CA akan ikut meningkat sebesar 0,714. Nilai koefisien regresi pada variabel CDA adalah sebesar 0,409. Ini berarti bahwa dengan faktor lain dianggap konstan, maka setiap peningkatan CDA maka CA akan ikut meningkat sebesar 0,409. Nilai koefisien regresi pada variabel NP adalah sebesar -0,168. Ini berarti bahwa dengan faktor lain dianggap konstan, pengaruh kompensasi lebih kecil dibandingkan dengan HRD dan CDA karena hasilnya adalah sebesar $-0,168$.

Beta untuk X1 = 0,660. Untuk X2 =0,321. Dan untuk X3 = -0.131. Dengan demikian variabel yang paling dominan, yang mempunyai koefisien beta $=0,660$ adalah HRDa diikuti oleh variabel CDAi dengan koefisien beta $=0,321$. Maka dengan mengacu pada hasil beta (Unstandartdized Coefficients) di atas dapat dihasilkan persamaan regresi sebagai berikut: $\mathrm{Y}=0.271+0.714 \mathrm{X} 1+0.409 \mathrm{X} 2-0.168$

\subsection{Uji Hipotesis dengan Uji Signifikansi dan Uji F}

Uji simultan dengan F-test bertujuan untuk mengetahui pengaruh bersama sama variabel independen terhadap variabel dependen.. Dari Uji ANOVA atau F-test, didapat F hitung adalah 31.990 dan dengan probabilitas 0,000. Probabilitas jauh lebih kecil $(<)$ dari 0,05 maka model regresi dapat digunakan untuk memprediksi Competitive Advantage .

Pada output SPSS tersebut juga menunjukkan p-value $0,000<0,05$ yang artinya adalah signifikan dalam hal ini, Ho ditolak atau Ha diterima. Dengan demikian dapat disimpulkan bahwa variable HRD, CDA, NP secara bersama-sama berpengaruh terhadap Competitve Advantage Perguruan Tinggi Keagamaan Islam (PTKIAN) di UIN Malang, Surabaya, Jogjakarta dan Bandung.

Berdasarkan hasil pengujian secara statistik dapat terlihat dengan jelas bahwa:

Secara simultan semua variabel bebas berpengaruh signifikan terhadap variable terikat dengan nilai sig. $0,000<\alpha 0,05$. Pengaruh yang diberikan ketiga variable bebas tersebut bersifat positif artinya semakin tinggi Human Resources Develpment (HDR) yakni pengembangan sumber daya manusia yang dapat meningkatkan mutu Tridharma perguruan tinggi dan pengembangan kualitas SDM secara berkelanjutan, Community Development Anaysis (CDA) yakni Peran/kontribusi PT dalammeningktkan kompetnsi masyarakat, peningkatan keterlibatan dan partisipasi masyrakta, pengembangan program-progra pemberdayaan yang tepat sasaran dan kesesuaian program dan hasil comdev dengan masyarakat pengguna, dan Networking \& Pathnership (NP) yakni kemampuan PT untuk membangun jejaring/berkelompok dan komunikasi dalam bekerjasama dengan berbagai pihak kepeningan maka mengakibatkan semakin tinggi pula Daya Comtetitive Advantage, yakni keunngulan dan daya saing suatu Perguruan Tinggi Keagamaan Islam (UIN) di Indonesia

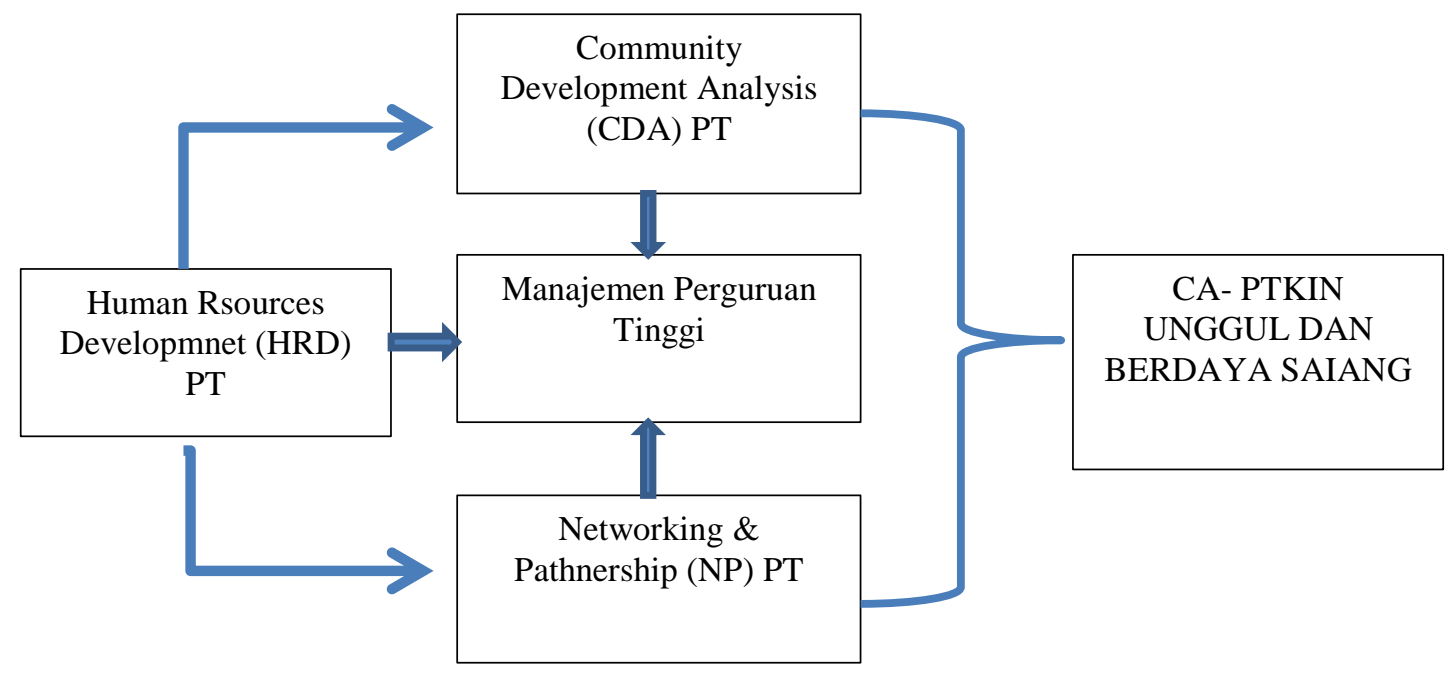

Gambar 2. Hasil Penelitian Secara Simultan

\section{Secara Parsial}

a. Pengaruh HRD terhadap CA

Hasil pengujian hipotesis (H1) telah membuktikan terdapat pengaruh antara HRD terhadap CA PT. Melalui hasil perhitungan yang telah dilakukan diperoleh nilai t hitung sebesar 8.493 dengan taraf signifikansi hasil sebesar 0,000 tersebut lebih kecil dari 0,05, dengan demikian Ha diterima dan Ho ditolak. Pengujian ini secara statistic membuktikan bahwa HRD PT berpengaruh positif terhadap CA PT artinya 
bahwa ada pengaruh antara variabel HRD PTKIN UIN Malang, Surabaya, Jogjakarta, dan Bandung, hal ini disebabkan dengan adanya HRD PT yang baik maka CA PTKIN UIN akan menjadi LEBIH tinggi atau lebih baik pula.

b. Pengaruh variabel CDA terhadap CA

Hasil pengujian hipotesis (H2) telah membuktikan terdapat pengaruh antara CDA terhadap CA PT. Melalui hasil perhitungan yang telah dilakukan diperoleh nilai t hitung sebesar 3.987 dengan taraf signifikansi hasil sebesar 0,000 tersebut lebih kecil dari0,05, yang berarti bahwa hipotesis dalam penelitian ini menerima Ha dan menolak Ho. Pengujian ini secara statistik membuktikan bahwa CDA berpengaruh positif terhadap CA PT artinya bahwa variabel CDA secara signifikan mempengaruhi CAPTKIN UIN Malang, Surabaya, Jogjakarta, dan Bandung disebabkan dengan adanya CDA yang baik maka CA akan baik, dengan demikian semakin PTKIN UIN dapat meningkatkan CDA maka CA juga akan semakin meningkat. c. Pengaruh NP terhadap CA

Hasil pengujian hipotesis (H3) telah membuktikan terdapat tidak ada pengaruh antara NP terhadap CA. Melalui hasil perhitungan yang telah dilakukan didapat nilai t hitung sebesar -1.628 dengan taraf signifikansi hitung sebesar 0,108 tersebut lebih besar dari 0,05 yang berarti bahwa hipotesis dalam penelitian ini menolak Ha dan menerima Ho. Pengujian ini secara statistik membuktikan bahwa NP tidak berpengaruh terhadap CA, artinya bahwa tidak ada pengaruh antara variabel NP terhadap kinerja CA PTKIN UIN . Hal ini disebabkan karena ada NP i lain dari PTKIN UIN yakni memiliki hambatan dalam komunikasi dan bekerjasama yang tinggi dengan lembaga laian untuk bersama-sama mamajukan lembaga yang memiliki daya saing dan berkompetisi tinggi sebagai PT yang menjadi pilihan mahasiswa dan rebutan masyarakat.

\section{KESIMPULAN}

Berdasarkan hasil kajian teori dan pengujian di lapangan dengan datan dan haasil pembahasan maka dapat disimpulkan sebagai berikut :

1. Kesemua variabel HRD, CDA, dan NP berpengaruh terhadap Competitive Advantage (CA) atau daya saing PTKIN baik dalam dimensi keunggulan mutu lulusan (produc Quality), mutu layanan (Service Quality), maupun keunggulan berkoompetitisi dalam pembiayaan dan mutu Pengelolaan kelembagaan (Price ) kecuali variabel Community Development Analysis (CDA) pengaruhnya lebih kecil disbanding lainya.

2. Hasil penelitian menunjukkan bahwa kesemua variabel berpengaruh terhadap competitive advantage kecuali variabel Community Devlopment analysis. Hasil penelitian tersebut dapat digambarkan dengan persamaan $\mathrm{Y}=0,271+0,714 \mathrm{X} 1-0.168 \mathrm{X} 2+0,409 \mathrm{X} 3$, di mana X1 = Human Resources deveopmnet (HRD), X2 = Community Devepment Analysis (CDA), dan X3 = Networking \& Pthnership 9NP). Artinya konstanta sebesar 0,271 menyatakan bahwa faktor faktor selain variabel $\mathrm{X} 1$, X2, dan X3 yang mempengaruhi Competitive Advantage sebesar 0,271. Koefisien HRD sebesar 0,714 menyatakan bahwa apabila variabel X1 bertambah satu satuan akan menambah pengaruh CA sebesar 0.714 dengan anggapan variabel CDA dan NP dalah konstan. Koefisien regresi X2 sebesar -0,168 Ini berarti bahwa dengan faktor lain dianggap konstan, pengaruh CDA lebih kecil dibandingkan dengan HRD dan NP. Dan apabila variabel X3 bertambah satu satuan akan menambah CA sebesar 0,409 dengan anggapanvariabel HRD dan CDA adalah konstan.

3. Diperoleh nilai koefisien regresi pada variabel HRD adalah sebesar 0,714 . Ini berarti bahwa dengan faktor lain dianggap konstan, maka setiap peningkatan HRD maka CA akan ikut meningkat sebesar 0,714. Nilai koefisien regresi pada variabel CDA adalah sebesar -0,168. Ini berarti bahwa dengan faktor lain dianggap konstan, pengaruh CDA lebih kecil dibandingkan dengan HRD dan NP karena hasilnya adalah sebesar $-0,168$. Sedangkan nilai koefisien regresi pada variabel NP adalah sebesar 0,409. Ini berarti bahwa dengan faktor lain dianggap konstan, maka setiap peningkatan NP maka CA akan ikut meningkat sebesar 0,409.

4. Hasil regresi antar variable HRD, CDA, NP terhadap CA dengan software SPSS versi 19.00 Nilai R2 (koefisien determinasi) sebesar 0,758. Hal ini menunjukkan bahwa besarnya variasi yang memberikan pengaruh bersama-sama anatar HRD, CDA, NP terhadap CA sebesar 75,8\% atau sisanya $24,2 \%$ dipengaruhi oleh faktor-faktor lain yang tidak diteliti.

5. Variabel Human Resources Development (HRD) dengan dimensi kualitas layanan pendidikan dan pengajaran, penelitian dan publikasi ilmiah, pengabdian kepada masyrakat, dan peningkatan kualitas dan kapasitas akademik para tenaga Pndidik dan kepndidikan di PTKAIN UIN secara signifikan berpengaruh positif terhadap peningkatan Competitive Advantage (CA). Nilai koefisien regresi pada variabel Human Resources Development (HRD) adalah sebesar 0,714. Ini berarti bahwa dengan faktor lain dianggap konstan, maka setiap peningkatan HRD yang dilakukan oleh PTKIN 
UIN di Indonesia maka Competitive Advantage (CA) akan ikut meningkat sebesar 0,714 atau, 71,4 $\%$

6. Variabel Community Development Analysis (CDA) dengan dimensi peran konstribusi Perguruan tinggi dalam meningkatkan kompetensi masyarakat, partisipasi atau keterlibatan masyarakaat, pengembangan program community development (Comdev), dan relevansi Comdev bagi masyarkat yang dilakukan PTKIAN UIN secara signifikan tidak berpengaruh positif (langsung) terhadap peningkatan Competitive Advantage (CA). Nilai koefisien regresi pada variabel Community Development Analysis (CDA) adalah s sebesar -0,168. Ini berarti bahwa dengan faktor lain dianggap konstan, pengaruh CDA lebih kecil dibandingkan dengan HRD dan NP karena hasilnya adalah sebesar $-0,168$.

Variabel Networking \& Pathnership (NPA) dengan dimensi Kemampuan PTKIAN dalam bekelompok dan bekomunikasi dalam membangun jaringan yang dilakukan PTKIAN UIN secara signifikan berpenrauh positif terhadap peningkatan Competitive Advantage (CA). Nilai koefisien regresi pada variabel Networking \& Pathnership (NPA)adalah sebesar -0,409. Ini berarti bahwa dengan faktor lain dianggap konstan, maka setiap peningkatan NP maka CA akan ikut meningkat sebesar 0,409 atau 40, $9 \%$.

\section{SARAN}

1. Hasil temuan penelitian ini memberikan informasi yang sangat penting bagi pengembangan PTKIN khusunya UIN di Indonesia dalam mepersiapkan mutu lulusan dan perguruan tingginya untuk siap berkompetisi di era globalisasi atau pasara bebas dan menjadi PTKIN menuju Word Class University (WCU)

2. Disarnkan bagi pengambil kebijakan PTKIN hendaknya mengambil kebijakan-kebijakan stategis untuk meningkatkan daya saiang perguruan tinggi dengan prioritas pengembangan HRD, Networking \& Pathnership dan program-program CDA yang tepat sasaran dan mendukung peningkatan mutu dosen dan mahasiswa

3. Disarankan bagi dosen, mahasiswa untuk dapat memperluas dan memperbanyak membangun kersama dengan masyarakat melalui Community development dalam peningkatan mutu tridarma perguruan tinggi.

\section{DAFTAR PUSTAKA}

Andrew H. 2009. Kekuatan Networking, Dalam http://pembelajar.com Tanggal 27 Januari

Amin M.Abullah. 2011. Masa Depan Perguruan Tinggi Islam. Kompas. Com. 28/04/2011

Bungin, Burhan. 2009. Metodologi penelitian Kuantitatif, Jakarta: Penerbit Kencana Prenada Media Grup

Dadang Iskandar. 2010. Manajemen Stratejik. Kuliah I. Dalam http://dangiskandar.blogspot.com. 4 Januari.

Hansen Don, R and Maryane M.Mowen. 1997. Cost Management : Accounting and Control. Cincinnati : South-Western College Publishing.

Kadir. 2010. Statistika untuk Penelitian Ilmu-ilmu Sosial, Jakarta: Penerbit Rosemata Sampurna.

Mustaqim Sirathal. 2008. Penguatan Masyarakat Dengan Program CD. Dalam http://1.blot.spot.com. 27 Februari.

Porter, Michael, E . 1985. Competitive Strategy. Ney York : The Free Press.

Shank, J.K., and Govindarajan. 1993. Strategic Cost Management. New York:The Free Press.

Journal of Research on Community Engagement Vol. 1, No. 1, September 2019: 20 - 27 
Srimindarti, Ceacilia dan MG. Kentris Indarti. 2003. "Value Chain Analysis:Pengelolaan Aktivitas untuk Menciptakan Keunggulan Kompetitif”. FokusEkonomi 2, 1-7, Semarang : STIE Stikubang

Srivastava, Paul. 1994. Strategic Management: Concept and Practices. Ohio:South-Western Publishing Co.

Zamhariri. 2008. Pengembangan Masyarakat: Perspektif Pemberdayaan dan Pembangunan, Komunitas, Jurnal Pengembangan Masyarakat Islam, Vol4, no. 1

Zulfikar. 2013. Analisis Regresi Multivariate Principle Component Dengan Metode Ordinary Least Square Terhadap Faktor-Faktor Yang Mempengaruhi Pendidikan Tinggi Islam Ber Competitive Advantage 